\title{
TINDAK PIDANA LINGKUNGAN HIDUP DALAM KAITANNYA DENGAN PEMANFAATAN ENERGI NUKLIR
}

\author{
Petrus Avelino Framayuka Tolang, Geradin Mayella Jivisina Kotan, \\ Unchianus Natalius Tety Nahak \\ Universitas Airlangga, Surabaya \\ Email: (linotolang@gmail.com)
}

\begin{abstract}
Abstrak
Penggunaan teknologi nuklir juga tidak luput dari kecelakaan. Kecelakaan nuklir disebabkan oleh terlalu banyak energi yang seringkali sangat berbahaya. Sehubungan dengan masalah nuklir dengan konsekuensi hukum dari penggunaan teknologi nuklir dan tanggung jawab pidana lingkungan. Penelitian ini menggunakan pendekatan yuridis normatif. Terkait dengan konsekuensi hukum yang ditimbulkan, harus dimintai pertanggungjawaban menurut hukum yang dalam hal ini pidana. Dalam kecelakaan nuklir yang berkaitan dengan lingkungan, individu dan perusahaan dapat dimintai tanggung jawab atas hukuman pidana sesuai dengan UU PPLH. Penanganan korporasi ini diklarifikasi oleh Peraturan Mahkamah Agung Republik Indonesia Nomor 13 Tahun 2016 tentang Prosedur Penanganan Tindak Pidana oleh Korporasi karena ketidakjelasan dalam kriminalisasi korporasi dalam UU PPLH. Adapun hukuman sebagai akibat pemanfaatan nuklir yang berdampak pada lingkungan sifatnya adalah ultimum remedium atau sebagai obat terakhir.
\end{abstract}

Kata kunci: Pemanfaatan Nuklir, Kecelakaan Nuklir, Tanggung Jawab

Pidana.

\begin{abstract}
By utilizing nuclear energy, humans get huge benefits. The use of nuclear technology is also not spared from accidents. Nuclear accidents are caused by too much energy which is often very dangerous. In relation to nuclear issues with the legal consequences of the use of nuclear technology and environmental criminal liability. This research uses a normative juridical approach. Related to the legal consequences caused, it should be held liable according to law which in this case is criminally. In nuclear accidents related to the environment, individuals and corporations may be held liable for criminal penalties in accordance with the PPLH Law. The handling of this corporation is clarified by the Supreme Court Regulation of the Republic of Indonesia Number 13 of 2016 concerning Procedures for Handling Criminal Acts by Corporations due to obscurity in the criminalization of corporations in the PPLH Law. As for punishment as a result of nuclear utilization which has an impact on the environment its nature is ultimum remedium or as a final remedy.
\end{abstract}

Keywords: Nuclear Utilization, Nuclear Accidents, Criminal Liability 


\section{PENDAHULUAN}

$\mathrm{P}$ erkembangan teknologi di dunia pada akhir-akhir ini sangat pesat seiring dengan inovasi dan daya cipta yang tinggi oleh manusia dalam kehidupannya.Kajian yang secara terus menerus ini menunjukkan bahwa dalam masa seperti ini perlu dikembangkannya suatu model penemuan-penemuan yang bersifat praktis dan menjangkau semua kalangan masyarakat.Nuklir merupakan salah satu penemuan yang belum lama ini dikembangkan dan pada saat ini menjadi salah satu potensi yang dikaji untuk dikembangkan di Indonesia.Kata Nuklir berarti bagian dari atau yang berhubungan dengan nukleus atom (inti atom). ${ }^{1}$ Dari nuklir inilah kemudian dikembangkan teknik nuklir.Teknik nulir adalah penerapan praktis bidang ilmu inti atom yang disarikan dari prinsipprinsip fisika nuklir dan interaksi antara radiasi dan material. ${ }^{2}$ Pengembangan teknologi nuklir saat ini sangat pesat, baik dikembangkan untuk senjata nuklir maupun sebagai penggunaan sipil.

Teknologi nuklir banyak diaplikasikan dalam berbagai bidang. Dengan memanfaatkan energi nuklir manusia mendapatkan keuntungan yang sangat besar. Berbeda jika digunakan untuk hal militer tentunya sangat berbahaya, mengingat ledakan yang dihasilkan dari bom nuklir begitu besar. Dalam bidang medis, Manfaat energi nuklir bagi manusia dalam bidang medis yakni sebagai diagnose dan juga terapi radiasi. Hal ini tentunya sangat berguna bagi mereka para penderita kanker.Pada bidang ini sering disebut juga sebagai kedokteran nuklir yang membantu menyembuhkan berbagai penyakit. Dalam bidang pertanian, manfaat tegnologi nuklir disebut sebagai iradiasi makanan merupakan proses memaparkan bahan makanan dengan menggunakan ionisasi radiasi yang bertujuan untuk menghancurkan bakteri, virus, maupun juga serangga yang terdapat pada makanan. Dalam bidang industry, manfaat teknologi nuklir seperti proses eksplorasi serta gas, mengukur kelembaban dan kepadatan serta sebagai perancangan konstruksi jalan. Dalam bidang pembangkit listrik, teknologi nuklir digunakan pembangkit listrik memberikan energi listrik sangat besar ketimbang energi dari fosil.Bebrapa negara telah menggunakan teknologi ini namun perlu kehati-hatian tingkat tinggi dalam penggunaannya sehingga tidak terjadi kebocoran. ${ }^{3}$

${ }^{1}$ https://id.m.wikipedia.org/wiki/Nuklir diakses tanggal 4 Mei 2019 Pukul 10:56 WIB

${ }^{2} \mathrm{Ibid}$.

${ }^{3}$ https://pendidikan.id/main/forum/diskusi-pendidikan/artikel-berita/2560-manfaat-energinuklir-bagi-manusia diakses tanggal 4 Mei 2019 Pukul 11:05 WIB 
Pemanfaatan tegnologi nuklir tidak luput juga dari kecelakaan.Kecelakaan nuklir diakibatkan oleh energi yang terlalu besar yang seringkali sangat berbahaya.Kecelakaan radiologis dan nuklir sipil sebagian besar melibatkan pembangkit listrik tenaga nuklir.Yang paling sering adalah pemaparan nuklir terhadap para pekerjanya akibat kebocoran nuklir.Kebocoran nuklir adalah istilah yang merujuk pada bahaya serius dalam pelepasan material nuklir ke lingkungan sekitar.Yang paling terkenal adalah kasus Three Mile Island di Pennsylvania dan Chernobyl di Ukraina. ${ }^{4}$

Dalam pemanfaatan teknologi nuklir juga sangat berkaitan dengan lingkungan hidup yang menjadi tempat pemanfaatannya dan juga yang kemudian memberi dampak terhadap lingkungan hidup. Adapun lingkungan hidup menurut Pasal 1 angka 1 UU Nomor 32 Tahun 2009 tentang Perlindungan dan Pengelolaan Lingkungan Hidup adalah kesatuan ruang dengan semua benda, daya, keadaan, dan makhluk hidup, termasuk manusia dan perilakunya, yang mempengaruhi alam itu sendiri, kelangsungan perikehidupan, dan kesejahteraan manusia serta makhluk hidup lain. Kebutuhan akan lingkungan bersih dan sehat merupakan kebutuhan dari setiap manusia. Di Indonesia secara yuridis mengenai lingkungan adalah hak asasi manusia yang termuat dalam Pasal 28H Ayat 1 Undang-Undang Dasar Negara Republik Indonesia 1945 yang menyatakan " Setiap orang berhak hidup sejahtera lahir dan batin, bertempat tinggal, dan mendapatkan lingkungan hidup yag baik dan sehat serta berhak memperoleh pelayanan kesehatan". Penggunaan teknologi nuklir juga secara yuridis telah ada dalam peraturan perundang-undangan di Indonesia yakni dengan diundangkannya Undang-Undang Nomor 10 Tahun 1997 Tentang Ketenaganukliran. Ini dilakukan guna mendukung pemanfaatan dan pengembangan di berbagai bidang kehidupan manusia. Pemanfaatan teknologi nuklir atas perintah UU tersebut kemudian membentuk Badan Pelaksana untuk penyelenggaraan penelitian dan pengembangan, penyelidikan umum, ekpoitasi dan eksplorasi bahan galian nuklir, produksi radioisotope untuk keperluan penelitian dan pengembangan, dan pengelolaan limbah radioaktif. ${ }^{5}$ Kemudian lagi dibentuk Badan Pengawas yang melaksanakan pengawasan terhadap segala kegiatan pemanfaatan tenaga nuklir yang menyelengarakan peraturan, perizinan dan inspeksi. ${ }^{6}$

Kegiatan Pemanfaatan teknologi nuklir inilah kemudian tidak selamanya membawa dampak baik bagi manusia tetapi dampak buruk juga.Salah satu

\footnotetext{
${ }^{4}$ Op.cit, https://id.m.wikipedia.org/wiki/Nuklir

5 Pasal 3 UU Nomor 10Tahun 1997 tentang Ketenaganukliran

${ }^{6}$ Pasal 4 UU Nomor 10Tahun 1997 tentang Ketenaganukliran
} 
dampak yang sangat membahayakan adalah terjadinya kecelakan atau kelalain dalam pemanfaatannya yang mempengaruhi kerusakan atau pencemaran terhadap lingkungan hidup yang kemudian menjadi fokus kajian saya mengenai tindak pidana lingkungan hidup dalam kaitannya dengan ketenaganukliran dengan isu akibat hukum terhadap pemanfaatan teknologi nuklir serta pertanggungjawaban pidana lingkungan sebagaimana akibat hukum yang ditimbulkan dari pemanfaatan teknologi nuklir. Adapun tujuan dari penulisan artikel ini adalah untuk mengetahui akibat hukum dari pemanfaatan energi nuklir terhadap lingkungan hidup serta membahas mengenai pertanggungjawaban pidana lingkungan hidup sebagai akibat kecelakaan nuklir.

\section{PEMBAHASAN}

\section{A. Akibat Hukum Pemanfaatan Teknologi Nuklir}

Tenaga nuklir saat ini telah menjadi salah satu alternatif yang menarik minat banyak negara dalam hal penggunaannya.Penggunaan tersebut dapat diterapkan di berbagai bidang kegiatan. Salah satu yang menjadi sangat terkenal belakangan ini adalah penggunaan tenaga nuklir sebagai reaktor nuklir yang lebih dikenal sebagai Pembangkit Listrik Tenaga Nuklir (PLTN). Penggunaan tenaga nuklir ini timbul karena adanya peningkatan kebutuhan energi yang aman untuk pertumbuhan serta masa depan, hampir separuh penduduk Indonesia belum menikmati listrik, pencegahan pemanasan global, dan peningkatan peran energi baru dan terbarukan. ${ }^{7}$

Di Indonesia melalui BATAN dan BAPETEN tengah gencar dilakukan pengenalan tenaga nuklir kepada masyarakat untuk digunakan sebagai pembangkit listrik guna menangani masalah pasokan listrik di Indonesia. Terkait dengan tenaga nuklir tersebut guna memenuhi kebutuhan maka dilakukan pemanfaatan yang didefenisikan dalam Pasal 1 angka 4 Undang-Undang Nomor 10 Tahun 1997 tentang Ketenaganukliran menjelaskan pemanfatan adalah kegiatan yang berkaitan dengan tenaga nuklir yang meliputi penelitian, pengembangan, penambangan, pembuatan, produksi, pengangkutan, penyimpanan, pengalihan, ekspor, impor, penggunaan, dekomisioning, dan pengolahan limbah radioaktif untuk meningkatkan kesejahteraan rakyat.

Tidak diragukan lagi bahwa tenaga nuklir, termasuk di dalamnya radiasi, banyak manfaatnya, meliputi berbagai bidang kehidupan dalam masyarakat dan negara. Hal ini disebabkan karena sifat radiasi yang mempunyai daya penetrasi

7 Ferhat Aziz, "Pembangkit Listrik Tenaga Nuklir dan Lingkungan", makalah disampaikan dalam seminar tentang nuklir tanggal 27 November 2007. 
terhadap benda-benda yang dilalui berbeda dengan cahaya nampak. Berhubung dengan sifat-sifat itulah radiasi sejak lama telah dimanfaatkan untuk mengetahui atau menghasilkan sesuatu yang diharapkan yang tidak dapat dicapai dengan cara konvensional.

Radiasi adalah pancaran energy melalui suatu materi atau ruang dalam bentuk panas, partikel atau gelombang elektromagnetik/ cahaya (foton) dari sumber radiasi. ${ }^{8}$ Adapun tenaga nuklir tergolong dalam sumber radiasi buatan yang ada karena dibuat oleh manusia yang mana sumber radiasi tersebut yang dalam bentuk unsur-unsur netral dengan radiasi gelombang elektromagnetik atau partikel melalui suatu reaksi nuklir yang kemudian sifatnya menjadi dapat memncarkan radiasi atau sebagai zat radioaktif. Radiasi juga terdiri dari berbagai jenis yakni Radiasi alpha, beta, gamma, neutron, sinar-X dll.radiasi ini jugatergolong dalam radiasi pengion atau jenis radiasi yang dapat menyebabkan efek ionisasi apabila berinterakis dengan sel-sel hidup. ${ }^{9}$ Menurut Pasal 1 Angka 3 Undang-Undang Nomor 10 Tahun 1997 tentang Ketenaganukliran yang dimaksud dengan radiasi pengion adalah gelembang elektromagnetik dan partikel bermuatan yang kerena energi yang dimilikinya mampu meng-ionisasi media yang dilaluinya. Sedangkan radiasi non pengion adalah jenis radiasi yang tidak akan menyebabkan efek ionisasi apabila berinteraksi dengan sel-sel hidup seperti gelombang radio, gelombang microwave, gelombang radar dll. ${ }^{10}$ Sehingga dapat dipahami disini yakni radiasi pengion merupakan jenis radiasi yang ada dalam pemanfaatan nuklir yang dapat memberikan energi.

Namun di balik sifat yang bermanfaat itu radiasi nuklir juga dapat mengandung sifat bahaya, yaitu agar sifat bahaya itu tidak mencelakakan manusia yang memanfaatkan, termasuk merusak lingkungan apabila pemanfaatannya tidak memenuhi ketentuan yang dipersyaratkan untuk itu. Radiasi tidak terlihat, tidak berwarna dantidak berbau, dan hanya dapat dideteksi dengan instrumen, dan mampu menimbulkan ionisasi pada benda yang dilalui. Radiasi mempunyai efek yang dapat merugikan pada sel tubuh manusia yang disebut efek deterministik atau stokastik. ${ }^{11}$

${ }^{8}$ Adiwardojo, Ruslan, Eko Madi Parmanto, Fakta Seputar Radiasi, PDIN-BATAN, Jakarta, 2010, h. 1

${ }^{9}$ Ibid, h. 2-6

${ }^{10}$ Ibid, h. 7

${ }^{11}$ Eri Hiswara, Buku Pintar Produksi dan Keselamatan Radiasi di Rumah Sakit, BATAN Press, Jakarta, 2015, h.2 
Secara prinsip, keselamatan manusia dan lingkungan adalah dua aspek utama yang harus menjadi tujuan dan harus diperhitungkan dan dipertimbangkan dalam pengoperasian suatu instalasi teknis. Apalagi untuk instalasi nuklir seperti halnya reaktor, masalah keselamatan dituntut lebih tinggi dibandingkan dengan instalasi non nuklir atau sering disebut instalasi konvensional karena terdapat tambahan potensi bahaya yaitu berupa kandungan zat radioaktif. Pada pengoperasian reaktor, di dalam bahan bakar nuklir terkandung banyak zat radioaktif yang disebut isotop produk fisi atau isotop hasil-belah yang bersifat radioaktif dalam jumlah dan aktivitas yang sangat besar. ${ }^{12}$

Pemanfaatan nuklir dalam kaitannya dengan lingkungan sangat perlu diperhatikan sebagai mana dalam Pasal 1 Angka 2 UU Nomor 32 Tahun 2009 Tentang Perlindungan dan Pengelolaan Lingkungan Hidup yang menyatakan "Perlindungan dan pengelolaan lingkungan hidup adalah upaya sistematis dan terpadu yang dilakukan untuk melestarikan fungsi lingkungan hidup dan mencegah terjadinya pencemaran dan/atau kerusakan lingkungan hidup yang meliputi perencanaan, pemanfaatan, pengendalian, pemeliharaan, pengawasan, dan penegakan hukum". Selanjutnya masih berkaitan dengan pasal tersebut diatas maka setidaknya dalam pemanfaatan nuklir seharusnya disertai dengan dokumen kajian seperti yang ada dalam Pasal 14 UU PPLH yakni Instrumen pencegahan pencemaran dan/atau kerusakan lingkungan hidup terdiri atas: a). KLHS; b). tata ruang; c). baku mutu lingkungan hidup; d). kriteria baku kerusakan lingkungan hidup; e). amdal; f). UKL-UPL; g). perizinan; h). instrumen ekonomi lingkungan hidup; i). peraturan perundang-undangan berbasis lingkungan hidup; j). anggaran berbasis lingkungan hidup; k). analisis risiko lingkungan hidup; 1). audit lingkungan hidup; dan $\mathrm{m}$ ). instrumen lain sesuai dengan kebutuhan dan/atau perkembangan ilmu pengetahuan.

Dokumen-dokumen seperti diatas dapat dikatakan sebagai syarat mutlak dalam pelaksanaan suatu kegiatan yang dalam hal ini mengenai pemaanfaatan tenaga nuklir dengan mengingat efek bahaya yang terjadi dikemudian hari terhadap lingkungan hidup. Terkait dengan sifat mencelakakan manusia dan lingkungan dari pemanfaatan nuklir dapat membawa akibat hukum. Dalam kepustakaan bahasa Indonesia terutama dalam kamus besar bahasa Indonesia akibat hukum diartikan sebagai akibat yang timbul dari suatu peristiwa hukum. ${ }^{\mathbf{1 3}}$ Dilihat dari segi isinya peristiwa hukum dapat terjadi karena keadaan tertentu, kejadian alam, dan kejadian fisik yang menyangkut kehidupan manusia.

\footnotetext{
${ }^{12}$ Iman Kuntoro, Keselamatan Reaktor Nuklir, BATAN Press, Jakarta, 2018, h. 13.

${ }^{13}$ https://kbbi.kata.web.id/akibat-hukum/ diunduh Kamis, 9 Mei 2019 Pukul 22:00
} 
Kejadian fisik yang menyangkut kehidupan seperti kelahiran, kematian dan usia tertentu yang menyebabkan seseorang dianggap cakap untuk melakukan tindakan hukum. ${ }^{\mathbf{1 4}}$ Tindakan hukum adalah tindakan yang diatur oleh hukum yaitu:

1. Tindakan menurut hukum misalnya jual beli, membuat testamen, melangsungkan perkawinan, dan lain-lain.

2. Tindakan yang dilarang dan diancam dengan pidana oleh undang-undang, misalnya jual beli narkoba, menghilangkan nyawa orang lain, dan lain-lain.

3. Tindakan yang melanggar hukum, misalnya perbuatan merugikan orang lain, persaingan curang, dan lain-lain.

4. Tindakan karena tidak memenuhi kewajiban yang didalam hukum hal itu disebut wanprestasi (default) misalnya tidak membayar hutang, tidak mengirim barang yang dipesan oleh pembeli dan lain-lain. ${ }^{15}$

Peristiwa hukum dan tindakan hukum menimbulkan akibat hukum yaitu akibat yang diatur oleh hukum. Penggunaan teknologi nuklir merupakan suatu peristiwa yang diatur dalam peraturan perundang-undangan secara khusus melalui Undang-Undang Nomor 10 Tahun 1997 Tentang Ketenaganukliran yang meliputi pemanfaatan, pengembangan, dan penguasaan ilmu pengetahuan dan teknologi nuklir serta pengawasan kegiatan yang berkaitan dengan nuklir. Dalam pemnfaatan dan pengembangan terkait ketenaganukliran ini merupakan sautu tindakan yang tidak menutup suatu kemungkinan terjadi suatu akibat hukum yakni kecelakaan nuklir yang kemudian didefenisikan dalam pasal 1 angka 15 yang menyatakan kecelakaan nuklir adalah setiap kejadian atau rangkaian kejadian yang menimbulkan kerugian nuklir.

Akibat dari kecelakaan ini menimbulkan hak asasi manusia menjadi terganggu dengan kerugian nuklir yang secara eksplisit didefenisikan dalam Pasal 1 angka 16 yaitu Kerugian nuklir adalah setiap kerugian yang dapat berupa kematian, cacat, cedera atau sakit, kerusakan harta benda, pencemaran dan kerusakan lingkungan hidup yang ditimbulkan oleh radiasi atau gabungan radiasi dengan sifat racun, sifat mudah meledak, atau sifat bahaya lainnya sebagai akibat kekritisan bahan bakar nuklir dalam instalasi nuklir atau selamapengangkutan, termasuk kerugian sebagai akibat tindakan preventif dan kerugian sebagai akibat atau tindakan untuk pemulihan lingkungan hidup.

Kemudian mengenai pencemaran lingkungan hidup inilah yang mana diatur dalam Pasal 1 Angka 14 yang mendefenisikan Pencemaran lingkungan hidup adalah masuk atau dimasukkannya makhluk hidup, zat, energi, dan/atau

\footnotetext{
${ }^{14}$ Peter Mahmud Marzuki, Pengantar Ilmu Hukum, 2008, Kencana, Jakarta, h. 210

15 Ibid, hlm. 210.
} 
komponen lain ke dalam lingkungan hidup oleh kegiatan manusia sehingga melampaui baku mutu lingkungan hidup yang telah ditetapkan. Dari penjabaran terkait perncemaran lingkungan hidup, dapat dimengerti bahwa dalam pemanfaatan tenaga nuklir berupa radiasi juga terjadi kemungkinan yang tidak diduga yakni kecelakaan nuklir yang dapat berupa kebocoran nuklir maupun kesalahan instalasi nuklir ataupun kejadian yang bukan karena manusia tetapi karena bencana alam. Dari pencemaran lingkungan ini kemudian terjadi akibat yang lain terhadap lingkungan hidup sebagai rangkaian dari pemanfaatan nuklir yakni kerusakan lingkungan hidup yang didfenisikan dalam Pasal 1 Angka 17 yang menyatakan "Kerusakan lingkungan hidup adalah perubahan langsung dan/atau tidak langsung terhadap sifat fisik, kimia, dan/atau hayati lingkungan hidup yang melampaui kriteria baku kerusakan lingkungan hidup”. Kerusakan ini sangat membahayakan kelangsungan hidup manusia yang mana dalam kehidupannya selalu menyatu dengan lingkungan hidup sehingga apabila lingkungan hidup yang sebagai tempat yang ditempati rusak maka hidupnya juga akan tidak aman. Ini bertautan dengan pemanfaatan nuklir yang apabila terjadi radiasi dari pengoperasian reaktor dalam kondisi tidak normal, gangguan dan kecelakaan maupun oleh sebab pengaruh dari luar instalasi reaktor. Pengaruh dari luar dapat berupa bencana alam dan kegiatan masyarakat termasuk tindak kejahatan manusia. ${ }^{16}$ Kerusakan lingkungan hidup akhirnya membawa dampak yang merugikan sebagai akibat dari terjadinya kebocoran reaktor nuklir ataupun pada saat instalasi nuklir sebagaimana didefenisikan dalam Pasal 1 angka 26 yang menyatakan "Dampak lingkungan hidup adalah pengaruh perubahan pada lingkungan hidup yang diakibatkan oleh suatu usaha dan/atau kegiatan. Dengan demikian pemanfaatan energi nuklir secara komersial haruslah mempunyai dokumen lingkungan hidup yang dipersyaratkan dalam UU PPLH. apabila terdapat kecelakaan nuklir sebagai akibat hukumnya ialah kerusakan lingkungan hidup yang berdampak pada lingkungan hidup dan kehidupan manusia yang hidup dalam suatu ekosistem lingkungan merasa terganggu akibat dari kecelakaan nuklir tersebut sehingga manusia berhak menuntut pertanggungjawaban atas tindakan yang embawa akibat hukum tersebut.

\section{B. Pertanggungjawaban Pidana Kecelakaan Nuklir}

Dalam setiap perbuatan yang disebut sebagai perbuatan hukum selalu dilakukan oleh subyek hukum. Adapun Subjek hukum adalah terjemahan dari bahasa Belanda rechtssubject. Subject dikenal dalam bahasa Inggris dan Belanda

${ }^{16}$ Loc.cit, Iman Kuntoro, h. 15. 
yang muasalnya dari kata Latin subjectus dan secara harafiah diartikan sebagai dibawah kekuasaan orang lain (subordinasi). ${ }^{17}$ Manusia dapat disebut sebagai subjek hukum pada masa ini selama ia masih hidup, sejak dilahirkan hingga meninggal dunia. Menurut Salmond, person dapat dibedakan menjadi manusia dan bukan manusia. Dalam literatur bahasa Belanda manusia dikenal sebagai natuurlijke person yang dalam bahasa Indonesia disebut orang dan bukan manusia disebut rechtspersoon yang artinya badan hukum. ${ }^{18}$

Dalam pemanfaatan tenaga nuklir tentunya tidak lepas dari subyek hukum seperti yang dijebarkan dalam Pasal angka 17 UU ketenaganuliran yang dalam pemanfaatannya terutama mengenai pengusaha instalasi nuklir terdi atas orang persorangan dan juga badan hukum yang bertanggung jawab atas pengoperasian instalasi nuklir. Selanjutnya dalam Pasal 7 ditentukan bahwa pemerintah dapat membentuk badan usaha milik negara yang berkaitan dengan pemanfaatan nuklir secara komersial. Maka sudah jelas bahwa dalam pertanggung jawaban terkait dengan pemanfaatan nulkir dapat dibebankan kepada orang perseorangan maupun badan hukum.

Jika dikaitkan dengan tindak pidana lingkungan hidup, maka subjek hukum dalam Undang-Undang Nomor 32 Tahun 2009 Tentang Perlindungan Dan Pengelolaan Lingkungan Hidup(Lembaran Negara Republik Indonesia Tahun 2009 Nomor 140, Tambahan Lembaran Negara Republik Indonesia Nomor 5059, untuk selanjutnya disingkat UU PPLH Subjek hukum yaitu "setiap orang" yaitu "orang perseorangan" dan/atau "badan usaha, baik yang berbadan hukum maupun yang tidak berbadan hukum maupun tidak berbadan hukum" (pasal 1 angka 32).

Mengenai pertanggungjawaban pidana, pertama-tama perlu ditelusuri terlebih dahulu mengenai perbuatan pidana yang dalam hal ini adalah tindak pidana.Perbuatan pidana menurut Moeljatno adalah perbuatan yang dilarang melalui suatu aturan hukum berupa larangan dan disertai dengan ancaman sanksi tertentu berupa pidana bagi siapa saja yang melanggar suatu aturan hukum tersebut. ${ }^{19}$ Selanjutnya Moeljatno juga mengemukakan elemen-elemen dari perbuatan pidana yang terdiri dari lima elemen yakni ${ }^{20}$ :

a. Kelakuan dan akibat (Perbuatan).

b. Hal ikhwal atau keadaan yang menyertai perbuatan.

17 Peter Mahmud Marzuki, Pengantar Ilmu Hukum, Kencana Prenadamedia, Jakarta, 2008, h. 205 .

\footnotetext{
${ }^{18}$ Ibid, h. 207.

${ }^{19}$ Moeljatno, Asas-Asas Hukum Pidana, Rineka Cipta, Yogyakarta, 2000, hlm. 59

${ }^{20}$ Ibid, hlm. 69
} 
c. Keadaan tambahan yang memberatkan pidana.

d. Unsur melawan hukum yang obyektif.

e. Unsur melawan hukum yang subyektif.

Dasar adanya tanggung jawab dalam hukum pidana seperti dikemukakan oleh Simons memberikan intinya bahwa pertanggungjawaban dalam hukum pidana adalah 1) keadaan psikis atau jiwa seseorang; dan 2) hubungan antara keadaan psikis dengan perbuatan yang dilakukan. ${ }^{21}$ Selanjutnya dari pertanggungjawaban pidana adalah mengenai suatu perbuatan pidana selalu diawali dengan adanya suatu kesalahan. artinya pengertian kesalahan dalam arti luas selalu identik dengan pertanggungjawaban dan pengertian yang kedua adalah kesalahan tidak hanya dilihat dari pengertian psikologis tetapi juga dikenal dalam pengertian hukum atau pengertian normatif. ${ }^{22}$ Kesalahan dalam pengertian psikologis adalah hubungan batin antara pelaku dan perbuatannya yang mana jika perbuatan tersebut dikehendaki maka perbuatan tersebut dilakukan dengan sengaja. ${ }^{23}$ Terdapat 2 teori mengenai kesengajaan yakni teori kehendak dan teori pengetahuan yang mana menurut Moeljatno tidak ada perbedaan antara kedua teori tersebut dengan mengemukakandidalam kehendak untuk melakukansesuatu sudah ada pengetahuan namun sebaliknya seorang yang mengetahui belum tentu menghedaki suatu perbuatan. ${ }^{24}$ Sedangkan jika perbuatan yang dilakukan tidak dikehendaki maka perbuatan tersebut merupakan suatu kealpaan. ${ }^{25}$ Kesalahan dalam pengertian normatif adalah penilaian dari luar dengan menggunakan ukuran-ukuran normatif yang kemudian menentukan apakah perbuatan tersebut dapat dicelakan kepada pelaku dan apakah perbuatan tersebut dapat dihidari atau tidak dihindari oleh pelaku. ${ }^{26}$

Mengenai pemanfaatan tenaga nuklir sebagaimana dalam Pasal 16 ayat 1 UU Ketenaganukliran secara tegas menyatakan bahwa "setiap kegiatan yang berkaitan dengan pemanfaatan tenaga nukli wajib memperhatiakan keselamatan, keamanan, dan ketentraman, kesehatan pekerja dan anggota masyarakat serta perlindungan terhadap lingkungan hidup." Pasal ini mau menjelaskan bahwa setiap pemanfaatan nuklir seharusnya wajib mempertimbangkan berbagai macam

${ }^{21}$ Eddy O.S. Hiariej, Prinsip-Prinsip Hukum Pidana, Cahaya Atma Pustaka, Yogyakarta, 2016, hlm. 156.

${ }^{22}$ Ibid, h. 159

${ }^{23}$ Ibid,

${ }^{24}$ Loc.cit, Moeljatno, h. 186-187.

${ }^{25}$ Op.cit, Eddy O.S. Hiariej, h. 159

${ }^{26}$ Ibid, 
aspek salah satunya adalah lingkungan hidup. Kerugian nuklir atas dilakukannya instalasi nuklir dan lainnya yang menyebabkan kerusakan terhadap lingkungan hidup menimbulkan harus adanya pertanggungjawaban atas terjadinya akibat tersebut yang mana dalam uraian sebelumnya bahwa pertanggungjawaban atas kecelakaan nuklir dapat diminta kepda pengusaha instalasi nuklir secara perseorangan maupun badan hukum.

Dalam pertanggungjawaban kecelakaan pemanfaatan nuklir terutama atas instalasi nuklir yang dilakukan oleh orang-perseorangan yang mengakibatkan kerusakan lingkungan hidup, maka seseorang tersebut dapat dimintakan pertanggungjawaban pidana. Sejalan dengan Pasal 28 UU Nomor 10 Tahun 1997 Tetang Ketenaganukliran yang menyatakan "pengusaha instalasi nuklir wajib bertanggungjawab atas kerugian nuklir yang diderita oleh pihak ketiga yang disebabkan oleh kecelakaan nuklir yang terjadi dalam instalasi nuklir tersebut". Dapat dijelaskan bahwa perseorangan tersebut wajib bertanggungjawab atas akibat hukum radiasi dari kecelakaan nuklir tersebut yang berdampak pada lingkungan hidup. Pertanggungjawaban secara pidana ini lebih lanjut diatur dalam ketentuan pidana lingkungan hidup pada Pasal 97 sampai dengan Pasal 120 UU PPLH.

Pertanggungjawaban secara perseorangan dapat terjadi sesuai ketentuan dalam pasal-pasal yang ada dalam ketentuan pidana UU PPLH yang mana jenis sanksi yang diberikan secara kumulatif antara pidana pokok berupa penjara dan juga denda. Dalam ketentuan tersebut juga mengatur pidana penjara dan denda secara minimum khusus dan maksimal khusus. Pertanggungjawaban pidana perseorangan ini juga dirumuskan dalam delik materiil.

Selain pertanggungjawaban secara perseorangan, kecelakaan nuklir yang mengakibatkan terjadinya kerusakan lingkungan hidup dapat juga dibebankan kepada korporasi atau dalam UU Ketenaganukliran dipersempitkan sebagai badan hukum. Pertanggungjawaban semacam ini dilakukan guna menjamin kepastian hukum dan memberikan perlindungan terhadap hak setiap orang untuk mendapatkan lingkungan hidup yang baik dan sehat. Antisipasi ini terlaksana guna melindungi lingkungan dari efek kecelakaan dari pemanfaatan nuklir berupa radiasi yang timbul dari pemaanfaatannya yang berdampak terhadap lingkungan secara luas.

Berkaitan dengan dapat dipertanggungjawabkan korporasi sebagai subjek hukum pidana telah dikenal di Indonesia sejak Tahun 1951. Korporasi layak untuk dimintakan pertanggungjawaban pidana apabila tindakannya tesebut bertentangan dengan hukum yang berlaku. Berkaitan dengan korporasi dapat dipertanggungjawabkan secara pidana, pada tataran doktrin, ada beberapa teori 
yang dapat dinilai yakni: Pertama, doktrin pertanggungjawaban yang ketat menurut undang-undang (strict liability), menekankan pertanggungjawaban korporasi semata-mata sesuai bunyi undang-undang tanpa memandang siapa yang melakukan kesalahan. Kedua, doktrin pertanggungjawban pengganti (vicarious liability), menekankan pada pertanggungjawaban oleh pengurus korporasi sebagai agen perbuatan korporasi tersebut. Ketiga, teori identifikasi (direct corporate criminal liability) atau doktrin pertanggungjawaban pidana secara langsung yang mana perbuatan/kesalahan senior officer diidentifikasi sebagai perbuatan/kesalahan korporasi. Keempat, teori agregasi menyatakan badan hukum dapat dibebankan pertanggungjawaban jika dilakuakan sejumlah orang yang memenuhi unsur delik yang mana antara satu dengan lainnya ada keterkaitan. Kelima, ajaran corporate cultur model yang menyatakan badan hukum dapat dipertanggungjawabkan secara pidana apabila tindakan seseorang memiliki dasar yang rasional bahwa badan hukum tersesbut memberikan wewenang atau mengizinkan perbuatan tersebut dilakukan. ${ }^{27}$

Dari uraian doktrin diata maka perlu diambil model pertanggungjawaban korporasi. Pertanggungjawab pidana korporasi, menurut Roeslan Saleh dapat ditemui tiga model pertanggungjawaban ${ }^{28}$ : Pertama, pengurus korporasi sebagai pembuat dan penguruslah yang bertanggungjawab. Pada model ini, bersandarkan pada dasar pemikiran bahwa badan hukum tidak dapat dipertanggungjawabkan secara pidana, karena penguruslah yang akan selalu dianggap sebagai pelaku dari delik tersebut. ${ }^{29}$ Kedua, korporasi sebagai pembuat dan pengurus yang bertanggungjawab.Dalam hal ini, sudah ditegaskan bahwa korporasi mungkin sebagai pembuat, namun untuk pertanggungjawaban diserahkan kepada pengurus.Tindak pidana yang dilakukan oleh korporasi adalah tindak pidana yang dilakukan orang tertentu sebagai pengurus dari badan hukum tersebut.Orang yang memimpin orporasi tersebutlah yang harus bertanggungjawab, terlepas pemimpin tersebut mengetahui perbuatan tersebut atau tidak.Namun, Roeslan Saleh berpendapat bahwa hal ini hanya berlaku untu pelanggaran saja, bukan kejahatan. ${ }^{30}$

27 Ibid, h, 206-207.

28 Eddy O.S Hairiej mengutip dari Setiyono, 2005, Kejahatan Korporasi; Analisis Viktimologi Dan Pertanggungjawaban Korporasi Dalam Hukum Pidana Indonesia, Bayumedia Publishing, Malang. hlm.131-132

${ }^{29}$ Eddy O.S. Hairiej mengutip Muladi dan Dwidja Priyanto, 2010, Pertanggungan Pidana Korporasi, cetakan pertama, kencana prenada group, Jakarta, hlm.83

${ }^{30}$ Loc. Cit. 
Ketiga, korporasi sebagai pembuat dan juga sebagai yang bertanggung jawab.Model ini memperlihatkan perkembangan korporasi itu sendiri, karena ternyata hanya dengan menetapkan pengurus sebagai yang dapat dipidana tidaklah cukup. Sebagaimana yang telah disebutkan sebelumnya, bahwa korporasi terkadang sebagai pihak yang diuntungkan dengan dilakukannya perbuatan pidana tersebut,sehingga pemidanaan terhadap pengurus tidak dapat menjamin bahwa korporasi tidak akan melakukan perbuatan pidana itu lagi.

Mengenai pertanggungjawaban pidana atas penggunaan nuklir komersil yang membawa akibat terhadap lingkungan hidup secara tegas yang dapat diminta pertanggungjawaban pidana menurut UU Nomor 32 Tahun 2009 Tentang Perlindungan Dan Pengelolaan Lingkungan Hidup(Lembaran Negara Republik Indonesia Tahun 2009 Nomor 140, Tambahan Lembaran Negara Republik Indonesia Nomor 5059, untuk selanjutnya disingkat UU PPLH) yakni orang perseorangan dan pelaku usaha baik berbadan hukum maupun tidak berbadan hukum. Undang-undang PPLH dalam BAB XV tentang KETENTUAN PIDANA, dijelaskan dalam pasal 97 sampai dengan 120, tentang jenis-jenis tindak pidana dan subjek pelaku tindak pidana lingkungan hidup. Beberapa catatan yang penting terkait dengan tindak pidana di lingkungan hidup, khususnya bagi pelaku korporasi, yaitu

1) Tindak pidana lingkungan hidup merupakan tindak pidana kejahatan (pasal 97). Hal ini mengandung konsekuensi yuridis bahwa setiap yang "mencoba" atau "membantu" tindak pidana ini juga diancam dengan pidana.

2) Tampak bahwa korporasi yang dimaknai "korporasi" disini yaitu "badan usaha" badan usaha ini meliputi badan hukum maupun non badan hukum.

3) Ketentuan pidana terhadap "badan usaha" diatur dalam Pasal 116,117, 118, dan 119

a. Pasal 116

Apabila tindak pidana lingkungan hidup dilakukan oleh, untuk, atau atas nama badan usaha, tuntutan pidana dan sanksi pidana dijatuhkan kepada

1. Badan usaha; dan/atau

2. Orang yang memberi perintah untuk melakukan tindak pidana tersebut atau orang yang bertindak sebagai pemimpin kegiatan dalam tindak pidana tersebut.

b. Terhadap tindak pidana sebagaimana dimaksud dalam pasal 116, sanksi pidana dijatuhkan kepada badan usaha yang diwakili oleh pengurus yang berwenang mewakili di dalam da di luar pengadilan sesuai dengan peraturan perundang-undangan selaku pelaku fungsional. 
4) Berdasarkan uraian angka 3 di atas, dapat diambil pemahaman bahwa uraian angka 3 diatas, dapat diambil pemahaman bahwa

a. Badan usaha dapat dimintai pertanggungjawaban pidana manakala tindak pidana lingkungan hidup tersebut dilakukan oleh badan usaha, untuk badan usaha, atas nama badan usaha.

b. Pertanggungjawaban pidana dapat dijatuhkan kepada

1. Badan usaha

2. Orang yang memberi perintah atau orang ang bertindak sebagai pemimpin kegiatan dalam tindak pidana tersebut

3. Badan usaha dan orang yang memberi perintah untuk melakukan tindak pidana tersebut atau orang yang bertindak sebagai pemimpin kegiatan dalam tindak pidana tersebut.

Menjadi pertanyaan dari segi UU PPLH mengenai sanksi pidana bagi pelaku badan usaha yakni dapat djatuhi pidana penjara sedangkan apa mungkin badan usaha dapat dijatuhi pidana penjara?. Kemudian tidak diatur secara khusus mengenai pidana denda yang secara khusus ditujukan kepada badan usaha. Lebih tegas lagi dinyatakan dalam pasal 118 UU PPLH yang mengatur sanksi bahwa badan usaha yang diwakili oleh pengurus yang berwenang mewakili yang mana semangatnya lebih kepada menjatuhkan pidana penjara kepada orang perseorangan $^{31}$. Selanjutnya mengenai pidana tambahan diatur dalam pasal 119 UU PPLH yang perlu dipahami bahwa pidana tambahan tidak dapat dijatuhkan secara mandiri, bersifat fakultatif yang mana dajatuhkan atau tidak maka terserah pada keputusan hakim dan harus diancamkan dalam pasal-pasal terlebih dahulu.dengan kata lain pidana tambahan tidak dapat dijatuhkan jika tidak diatur. $^{32}$

Perdebatan dapat terjadi dalam pertanggungjawaban korporasi terkait ketentuan pidana dalam UU PPLH, jika dikaitkan dengan kecelakaan dalam pemanfaatan tenaga nuklir yang mana radiasi dari nuklir dapat menyebabkan kerusakan lingkungan. Dalam UU ketenaganukliran, demikian tidak diatur ketentuan pidana mengenai korporasi ataupun perseorangan dapat dimintakan pertanggungjawaban secara pidana. Begitupun dalam UU PPLH korporasi dapat dipertanggungjawabkan secara pidana akibat kerusakan maupun pengrusakan lingkungan hidup telah diatur baik dalam bentuk kesengajaan ataupun kealpaan namun yang menjadi persoalan kemudian adalah bentuk penanganan terhadap

31 Didik Endro Purwoleksono, Hukum Pidana: Untaian Pemikiran, 2009, Airlangga University Press, Surabaya, h. 125.

${ }^{32}$ Ibid, h. 125. 
korporasi yang menimbulkan akibat alam hal ini terkait pemanfaatan tenaga nuklir yang membawa akibat hukum terhadap lingkungan hidup. Bentuk penanganan tersebut berupa sanksi yang akan diterima korporasi berupa pidana penjara yang sebenarnya tidak lazim.

Ketidaklaziman pemidanaan penjara kepada korporasi atau badan usaha dalam UU PPLH kemudian dapat dijawab lewat Peraturan Mahkamah Agung. Dalam kaitannya pula dapat dilihat dari Peraturan Mahkamah Agung Republik Indonesia Nomor 13 Tahun 2016 Tentang Tata Cara Penanganan Perkara Tindak Pidana Oleh Korporasi, Makna tindak pidana oleh Korporasi merupakan tindak pidana yang dilakukan oleh orang berdasarkan hubungan kerja, atau berdasarkan hubungan lain, baik sendiri-sendiri maupun bersama-sama yang bertindak untuk dan atas nama Korporasi di dalam maupun di luar Lingkungan Korporasi. Pertanggungjawaban Pidana Korporasi, sebagaimna diatur dalam pasal 4 ayat (1) bahwa Korporasi dapat dimintakan pertanggungjawaban pidana sesuai dengan ketentuan pidana Korporasi dalam undang-undang yang mengatur tentang Korporasi. Hal ini mengandung makna, bahwa korporasi dapat dijerat dengan pidana, manakala undang-undang tersebut dengan jelas mengatur tentang korporasi, termasuk di sini jenis pidananya berupa pidana denda. Mengeni pidana denda ini secara eksplisit termuat dalam Pasal 25 yang mana dinyatakan dalam ayat 1 "Hakim menjatuhkan pidana terhadap Korporasi berupa pidana pokok dan/atau pidana tambahan. selajutnya dalam ayar 2 dan 3 secara berturut-turut menyatakan "Pidana pokok yang dapat dijatuhkan terhadap Korporasi sebagaimana ayat (1) adalah pidana denda" dan "Pidana tambahan dijatuhkan terhadap Korporasi sesuai dengan ketentuan peraturan perundang-undangan”. Dapat dipahami bahwa dalam menjatuhkan pemidanaan terhadap korporasi berdasarkan pedoman yang dikelarkan oleh Mahkamah Agung maka hakim dapat mejatuhkan berupa pidana denda kepada korporasi sebagai pidana pokok dan juga pidana tambahan yang telah ada dalam perma tersebut di Pasal 31, Pasal 32 dan Pasal 33 berupa perampasan barang bukti, uang pengganti, ganti rugi, restitusi, perbaikan kerusakan akibat dari tindak pidana.

Dengan demikian terkait dengan kecelakaan nuklir yang mengakibatkan kerusakan lingkungan pertanggungjawaban pidana dapat ditanggung oleh orangperseorangan maupun korporasi atau dalam UU Ketenaganukliran lebih kepada badan hukum. Adapun bentuk pemidanaan untuk orang perseorang mengacu kepada UU PPLH sedangkan bentuk pidana pokok maupun pidana tambahan terhadap korporasi atau badan hukum lebih diutamakan kepada Peraturan Mahkamah Agung Nomor 13 tahun 2016 terkait Tata Cara Penanganan Perkara Tindak Pidana Oleh Korporasi. Ini karena terjadi ketidakjelasan pemidanaan 
terhadap korporasi dalam UU PPLH yang menghukum korporasi dengan pidana penjara yang mana lebih tertuju pada pengurus korporasi yang berwenang mewakili sehingga dianggap hukuman lebih ditekankan pada orang-perseorangan.

Pengaturan mengenai pertanggungjawaban pidana kecelakaan pemanfaatan nuklir ini lebih diutamakan kepada perlindungan terhadap lingkungan hidup yang mana telah diamanatkan dalam konstitusi Negara Republik Indonesia dalam Pasa $28 \mathrm{H}$ Ayat 1 yang menegaskan bahwa "Setiap orang berhak hidup sejahtera lahir dan batin, bertempat tinggal, dan mendapatkan lingkungan hidup yang baik dan sehat serta berhak memperoleh pelayanan kesehatan" yang kemudian dipertegas lagi dalam Pasal 5 Ayat (1) UUPLH yang berbunyi: "Setiap orang mempunyai hak yang sama atas lingkungan hidup yang baik dan sehat" serta UU No. 39 Tahun 1999 tentang Hak Asasi Manusia yang dalam pasal 9 ayat (3) menegaskan: "setiap orang berhak atas lingkungan hidup yang baik dan sehat".

Ketentuan pidana mengenai akibat dari pemanfaatan nuklir yang membawa dampak pada lingkungan hidup ini juga dikategorikan sebagai ultimum remidium yang mana dalam ketentuan pidana UU Ketenagan nukliran hanya mengatur mengenai hukuman pidana bagi pemanfaatan nuklir tanpa perizinan sedangkan yang lebih diutamakan adalah ganti kerugian yang mana berada dalam ranah hukum perdata. Ketentuan pidana dalam UU PPLH juga merupakan obat atau sarana terakhir dalam penegakan hukum dibidang lingkungan hidup. Dengan demikian pemanfaatan nuklir yang berakibat pada rusaknya lingkungan hidup dapat digunakan penegakan hukum menggunakan UU PPLH sejalan dengan asas hukum yakni lex specialis sistematis yang mengandung makna delik khusus dalam tindak pidana khusus.

\section{PENUTUP}

Pemanfaatan energi nuklir tidak lepas dari akibat hukum. akibat hukum itu berupa kecelakaan nuklir yang menimbulkan adanya kerugian yang berasal dari radiasi atau gabungan radiasi. Ini berdampak pada lingkungan hidup berupa kerusakan yang membawa efek negatif bagi manusia dan juga ekosistem secara umum. Kecelakaan nuklir ini bisa saja terjadi pada saat instlasi maupun saat kebocoran reactor nuklir sehingga percemaran lingkungan tidak dapa dihindari. akibat hukum ini terjadi karena kesengajaan ataupun kelalaian. Selain kesengajaan dan kelalain kecelakaan nuklir dapat terjadi karena bencana alam. Terkait akibat hukum yang ditimbulkan maka selayaknya dapat dimintakan pertanggungjawaban secara hukum yang dalam hal ini secara pidana. Dalam kecelakaan nuklir yang berkaitan dengan lingkungan hidup, orang-perseorangan maupun korporasi dapat 
dimintakan pertanggungjawaban pidana yang pengukumannya sesuai dengan UU PPLH berupa pidana pokok penjara bagi orang-perseorangan dan juga korporasi ataupun badan hukum dengan pidan pokok berupa pidana denda dan juga pidana tambahan berupa berupa perampasan barang bukti, uang pengganti, ganti rugi, restitusi, perbaikan kerusakan akibat dari tindak pidana. Penanganan bagi korporasi ini diperjelas dengan Peraturan Mahkamah Agung Republik Indonesia Nomor 13 Tahun 2016 Tentang Tata Cara Penanganan Perkara Tindak Pidana Oleh Korporasi karena ketidakajelasan dalam pemidanaan terhadap korporasi dalam UU PPLH. Adapun pemidanaan sebagai akibat dari pemanfaatan nuklir yang berdampak pada lingkungan hidup sifatnya adalah ultimum remedium atau sebagai obat terakhir.

Perlu pembaharuan dari regulasi mengenai ketenaganukliran yang mengatur sacara ketat tentang pemanfaatan nuklir secara komersil. Pembaharuan regulasi dibidang lingkungan hidup mengingat semakin banyak korporasi yang bermasalah dengan hukum dapat dijerat dengan peraturan yang jelas dan pasti sehingga tidak menimbulkan konflik atupun kekosongan aturan. Pentinganya pengawasan terhadap pemanfaatan nuklir guna mengkaji efek yang akan timbul di waktu mendatang sehingga ada langkah-langkah serius dalam mengatasi akibat dari pemanfaatan nuklir barupa kecelakaan baik karena keadaan alam ataupun dari manusia itu sendiri. 


\section{DAFTAR PUSTAKA}

\section{Buku}

Andi Hamzah, Penegakan Hukum Lingkungan, Sinar Grafika, Jakarta, 2008

Eddy O.S. Hiariej, Prinsip-Prinsip Hukum Pidana, Cahaya Atma Pustaka, Yogyakarta, 2016.

Fachruddin M. Mangunjaya, "Hidup Harmonis Dengan Alam: Esai-Esai Pembangunan Lingkungan, Konservasi dan Keanekaragaman Hayati Indonesia", (Jakarta: Yayasan Obor Indonesia, 2006),

Ferhat Aziz, "Pembangkit Listrik Tenaga Nuklir dan Lingkungan", makalah disampaikan dalam seminar tentang nuklir tanggal 27 November 2007.

Setiyono, 2005, Kejahatan Korporasi; Analisis Viktimologi Dan Pertanggungjawaban Korporasi Dalam Hukum Pidana Indonesia, Bayumedia Publishing, Malang.

Muladi dan Dwidja Priyanto, 2010, Pertanggungan Pidana Korporasi, cetakan pertama, kencana prenada group, Jakarta.

Leden Marpaung, Unsur-Unsur Perbuatan Yang Dapat di Hukum, Sinar Grafika,Jakarta, 1991.

Peter Mahmud Marzuki, Pengantar Ilmu Hukum, 2008, Kencana, Jakarta.

Rencana Pembangunan Reaktor Nuklir Ditolak, Suara Pembaruan, Kamis 1 Maret 2007.

Roeslan Saleh, Perbuatan Pidana Dan Pertanggungjawaban Pidana, Aksara Baru, Jakarta, 1983.

Siswanto Sunarso, "Hukum Pidana Lingkungan Hidup dan Strategi Penyelesaian Sengketa”, (Jakarta: Rineka Cipta, 2005)

Moeljatno, Asas-Asas Hukum Pidana, Rineka Cipta, Yogyakarta, 2000.

Adiwardojo, Ruslan, Eko Madi Parmanto, Fakta Seputar Radiasi, PDIN-BATAN, Jakarta, 2010.

Eri Hiswara, Buku Pintar Produksi dan Keselamatan Radiasi di Rumah Sakit, BATAN Press, Jakarta, Iman Kuntoro, Keselamatan Reaktor Nuklir, BATAN Press, Jakarta, 2018.

Ferhat Aziz, "Pembangkit Listrik Tenaga Nuklir dan Lingkungan", makalah disampaikan dalam seminar tentang nuklir tanggal 27 November 2007. 